\title{
МІЖНАРОДНО-ПРАВОВІ СТАНДАРТИ ОСОБИСТОЇ АВТОНОМІЇ В АКАДЕМІЧНІЙ КУЛЬТУРІ ТА НАУКОВОМУ СПІВРОБІТНИЦТВІ
}

\section{Шеляженко Юрій Вадимович}

асистент,

Університет «КРОК», м. Київ, Україна

ORCID: 0000-0003-3101-3878

sheliazhenkoiuv@krok.edu.ua
Надіслано:

19.10 .2019

Рецензовано:

03.11.2019

Прийнято:

15.12.2019

Актуальність дослідження зумовлена світовою дискусією про свободу досліджень в умовах трансформації методів оцінки ефективності науки, фінансування та організації досліджень, а також українським контекстом освітньої реформи. Метою статті $\epsilon$ дослідження міжнародно-правового стандарту особистої автономії у науковому житті та академічній культурі, його значення для розвитку глобального науково-технічного співробітництва України. Методи аналізу та синтезу застосовані для вивчення правових відносин та нормативних гарантій особистої автономії в академічній культурі та науковому співробітництві. Метод порівняння застосовано для виявлення спільних та відмінних проблем розвитку особистої автономії науковців в Україні та світі. Відповідно до висновків дослідження, міжнародно-правовий стандарт особистої автономії в академічній культурі та науковому співробітництві передбачає прагнення індивідуальної й інституційної самостійності та відповідальності в пошуку та передачі знань, вимагає поваги до свободи наукових досліджень, академічного спілкування та вираження поглядів. Цей стандарт пов'язаний із людською гідністю, метою освітньої системи досягти здатності людини контролювати власне життя, бути успішним i щасливим громадянином у демократичному інформаційному суспільстві. Загрозами особистій автономії науковців $\epsilon$ академічна недоброчесність, монополізм, патерналізм, формалізм та бюрократизм, що долаються шляхом самоорганізації вчених. Новий Закон України «Про освіту» створює інструменти для боротьби з академічною недоброчесністю, дозволяє проявляти ініціативу для удосконалення науки та освіти, хоча підзаконними актами все ще нав'язуються спірні стандарти якості науки, наприклад, вимога наявності публікацій у періодичних виданнях, індексованих наукометричними базами Scopus чи Web of Science, для присвоєння вчених звань. Українська академічна культура потребує оновлення, щоб підняти рівень наукових досліджень 
і створити основу конкурентоспроможної інноваційної економіки. Необхідно розбудовувати українську інфраструктуру наукової інформації, вітчизняні академічні видавництва, системи індексації та бібліотеки, посилювати правові гарантії особистої автономії, підтримувати проекти міжнародного науковотехнічного співробітництва, впровадження наукових розробок у економіці та суспільному житті. Значимість дослідження полягає в тому, що проведений аналіз дозволив сформулювати пропозиції і прогнози щодо прагматичної лібералізації наукового життя в Україні.

Ключові слова: особиста автономія; академічна культура; міжнародне науково-технічне співробітництво; наукометрія.

\section{Sheliazhenko Yurii, Research Associate, "KROK" University, Kyiv, Ukraine International Legal Standards of Personal Autonomy in Academic Culture and Scientific Cooperation}

This study is relevant to global discussions concerning freedom of research in view of transformations in science effectiveness evaluation, funding and research organization, as well as Ukrainian context of educational reform. Main objectives of the article are to study international legal standard of personal autonomy in scientific life and academic culture, the role of personal autonomy in Ukraine's global scientific and technical cooperation development. Methods of analysis and synthesis are used to study legal relations and normative guarantees of personal autonomy in academic culture and scientific cooperation. Comparison method is used to identify common and distinct problems in the development of scholars' personal autonomy in Ukraine and in the world. In conclusion, international legal standards of personal autonomy in academic culture and scientific cooperation prescribe imperative of individual and institutional independence and responsibility in the search and transfer of knowledge, demands respect for the freedom of scientific research, academic communication, and expression of views. This standard is connected with human dignity, the goal of education to develop human abilities to control own life, to be a successful and happy citizen in a democratic information society. Self-organization of scientists helps to overcome threats to personal autonomy, such as academic dishonesty, monopolism, paternalism, formalism, and bureaucracy. New Ukrainian law on education creates instruments for combating academic dishonesty and allows initiatives for science and education improvement, although administrative regulations still impose controversial standards of scientific quality, for example, the requirement of publications in periodicals indexed by scientometric databases Scopus or Web of Science to confer academic rank. Ukrainian academic culture needs modernization to raise the scientific research and create the basis of a competitive innovative economy. It is necessary to develop the Ukrainian infrastructure of scientific information, including scholarly publishers, indexes, and libraries, 
to strengthen legal guarantees of personal autonomy, to support projects of international scientific and technical cooperation, application of scientific results in economics and social life. So, the significance of study in formulated proposals and predictions regarding pragmatic liberalization of scientific life in Ukraine.

Key words: personal autonomy; academic culture; international scientific and technical cooperation; scientometrics.

Шеляженко Юрий Вадимович, ассистент, Университет "КРОК", 2. Киев, Украина

Международно-правовые стандарты личной автономии в академической культуре и научном сотрудничестве

Актуальность исследования обусловлена всемирной дискуссией о свободе исследований в условиях трансформации методов оценки эффективности науки, финансирования и организации исследований, а также украинским контекстом образовательной реформы. Целью этой статьи является исследование международно-правового стандарта личной автономии в научной жизни и академической культуре, его значения для развития глобального научно-технического сотрудничества Украины. Методы анализа и синтеза применены для изучения правовых отношений и нормативных гарантий личной автономии в академической культуре и научном сотрудничестве. Метод сравнения применен для выявления сходства и разницы проблем развития личной автономии ученых в Украине и мире. Согласно выводам исследования, международно-правовой стандарт личной автономии в академической культуре и научном сотрудничестве предусматривает стремление к индивидуальной и институциональной самостоятельности и ответственности в поиске и передаче знаний, требует уважения к свободе научных исследований, академического общения и выражения мнений. Этот стандарт связан с человеческим достоинством, целью образовательной системы достичь способности человека контролировать собственную жизнь, быть успешным и счастливым гражданином в демократическом информационном обществе. Угрозы личной автономии ученых составляют академическая недобросовестность, монополизм, патернализм, формализм и бюрократизм, которые преодолеваются путем самоорганизации ученых. Новый Закон Украины «Об образовании» создает инструменты для борьбы с академической недобросовестностью и позволяет проявлять инициативу для совершенствования науки и образования, хотя подзаконными актами все еще навязываются спорные стандарты качества науки, например, требование наличия публикаций в периодических изданиях, индексируемых наукометрическими базами Scopus или Web of Science, для присвоения ученых 
званий. Украинская академическая культура нуждается в обновлении, чтобы поднять уровень научных исследований и создать основу конкурентоспособной инновационной экономики. Необходимо развивать украинскую инфраструктуру научной информации, отечественные академические издательства, системы индексации и библиотеки, усиливать правовые гарантии личной автономии, поддерживать проекты международного научно-технического сотрудничества, внедрение научных разработок в экономике и общественной жизни. Значимость исследования состоит в том, что проведенный анализ позволил сформулировать предложения и прогнозы относительно прагматической либерализации научной жизни в Украине.

Ключевые слова: личная автономия; академическая культура; международное научно-техническое сотрудничество; наукометрия.

\section{Вступ}

У сучасному глобалізованому світі науково-технічний прогрес та академічна культура $\epsilon$ головними чинниками соціально-економічного благополуччя, індивідуального та інституційного розвитку. Інтелектуальний потенціал, основа багатства та конкурентоспроможності націй, визначається здатністю громадян самостійно мислити та діяти, приймати розумні рішення і брати на себе відповідальність за власне та суспільне благополуччя. Найвищий рівень економічної потужності показують нації, що поставили за мету освіти та науки розвиток особистої автономії.

\section{Аналіз останніх досліджень і публікацій}

Френк Вітте у книзі «Від наукового прогресу до економічного росту» (Witte, 2017)звертає увагу на те, що останні кілька століть значний науковотехнічний прогрес супроводжується підвищенням рівня життя людей.

Порівнюючи різні фактори економічного росту, такі, як клімат, географія, модернізаційні процеси, психологічні настрої, культура, залежність бідних націй від глобального капіталізму, ринкова економіка, Річард Лінн і Тату Ванханен у монографії«IQ та багатство націй» (Lynn, Vanhanen, 2002)приходять до висновку, що найважливішим фактором є розумовий розвиток людей.

Автори розвідки «Продуктивність у фізичних та хімічних науках дозволяє краще передбачити майбутній економічний ріст країн, що розвиваються, ніж інші популярні рейтинги» (Jaffeetal, 2013) порівнюють показники різних економетричних рейтингів і звертають увагу на те, що зростання частки публікацій з природничих наук у загальній кількості наукових публікацій корелює із зростанням валового внутрішнього продукту.

Дослідження Вернона Ратена «Знання суспільних наук та економічний розвиток» (Ruttan, 2003)показує, що інституційні інновації, рушій економічного 
розвитку стають більш доступними i менш витратними через прогрес соціальних наук та, відповідно,професійний ріст фахівців з права, управління, планування; завдяки успіхам соціальних наук технологічні інновації збагачують національну культуру, стають предметом конструктивного суспільного консенсусу та продуктивних колективних дій. 3 точки зору соціології, культурний та інноваційний динамізм сучасного суспільства визначається такими характеристиками: індивідуальна свобода та відповідальність, критичне мислення, автономія дій, філософія пізнання себе на власному досвіді.

Автором цієї статті у публікації «Академічна автономія та перспективи міждисциплінарних досліджень: математичний аналіз права» (Sheliazhenko, 2019) проаналізовано виклики академічній автономії як самовизначенню осіб та інституцій у сфері освіти та науки, особливо у сфері права, та запропоновано низку підходів, щоб впоратися з цими викликами, включаючи прагматизм і ширше використання математичних методів.

\section{Виділення невирішених раніше частин загальної проблеми}

У вітчизняній науці бракує критичних досліджень глобальних стандартів академічної культури та проблематики їх імплементації в Україні, зокрема,у аспекті зміцнення особистої та інституційної автономії.

\section{Формулювання мети і завдань статті}

Наше дослідження ставить собі за мету проаналізувати міжнародноправовий стандарт особистої автономії у науковому житті та академічній культурі, встановити його значення для розвитку глобального науковотехнічного співробітництва України.

\section{Виклад основного матеріалу дослідження}

Свобода поширення інформації та свобода наукової творчості, особиста автономія науковців захищена широким колом міжнародних та національних правових актів, серед яких можна назвати ст.ст. 19, 27 Загальної декларації прав людини, ст. 10 Конвенції про захист прав людини і основоположних свобод, ст. ст. 3, 24, 34,54 Конституції України, ст. 46 Закону України «Про наукову і науково-технічну діяльність» тощо.

У доповідях представників у галузі культурних прав Ради ООН з прав людини неодноразово підкреслювалося значення особистої автономії для глобального утвердження людських прав. Фарида Жагід наголошує, що наука і культура важливі не тільки для розвитку економіки знань, але й становлять основу людської гідності та автономії, і критикує міжнародно-правове регулювання інтелектуальної власності за відірваність від парадигми прав людини, надання переваги економічним інтересам похідних правовласників (наприклад, видавців), що мають більший за творців вплив на законодавчий процес, в ущерб особистій автономії авторів, креативній та академічній свободі 
вираження поглядів (Report of the Special Rapporteur, 2014). Карима Бенун вказує,

що перетворення культурних прав на розкіш, доступну лише провідній верстві, нереалізованість культурних прав разом із соціально-економічною нерівністю заважає людям насолоджуватися особистою автономією та правом на розвиток, користуватися своїми громадянськими і політичними правами (United Nations, 2016).

Існуюча світова модель наукової та освітньої інфраструктури передбачає грантове фінансування досліджень на міжнародному та національному рівні, як за приватні, так і за публічні кошти. Фінансуванню підлягають реалістичні проекти продуктивних вчених, причому перевага надається дослідникам 3 бездоганною репутацією, 3 відомих наукових установ, з історією наукових публікацій у рецензованих виданнях. Організація рецензування для підтвердження наукової новизни та значимості публікації $\epsilon$ однією з передумов академічної автономії наукових журналів та видавництв, їх здатності самостійно організувати цикл підготовки статей до оприлюднення (Sheliazhenko, 2017).

Ситуація у науковій видавничій справі сьогодні є однією з глобальних проблем, що особливо турбує науковців. Мартін Ів та Ернесто Пріего критикують хижацькі академічні видавництва, які за великі гроші беруться організувати якісне рецензування в наукових журналах, чого насправді не роблять (Eve, Priego, 2017).

Колективом авторів за участі Емануеля Кульчицького, радника Міністерства науки і вищої освіти Польщі, було доведено, що численні наукові журнали готові взяти в редакційну колегію вигаданого науковця з сумнівною біографією, яка б не витримала навіть поверхової перевірки. 483360 журналів, на адресу яких було розіслано пропозицію співпраці від «докторки Анни Ошуст» («oszust» польською - «шахрайство»), включили ії до списку редакторів (Sorokowski, Kulczycki, Sorokowska, Pisanski, 2017).

Адам Маркус та Іван Оранський описують численні випадки фальсифікації даних наукових досліджень, біографічних даних науковців і навіть співавторів. Так, у 80-х роках минулого століття фізик Вільям Гувер, отримавши дві відмови у публікації статті, втретє таки зумів її опублікувати, коли додав для солідності вигаданого співавтора 3 іноземного наукового інституту. Виправдовуючись за неетичну поведінку, інший фальсифікатор послався на те, ніби вчені давно вже не публікуються, щоб поділитися результатами досліджень 3 колегами, натомість дбають лише про накручування «метрик» - свого рейтингу за формальними показниками (Marcus, Oransky, 2016). Хоча подібні виправдання викликають мало симпатії, доля правди у них $\epsilon$. 
Дієго Каваро, Ісмаел Рафолс і Пуей Тан у статті «Навіщо дослідники публікуються не у мейнстрімових журналах: тренування, поширення знань та заповнення пробілів» звертають увагу на те, що оцінки досліджень на основі рейтингів журналів систематично маргіналізують знання з певних регіонів та галузей науки. Наприклад, дослідження з ботаніки маракуї та хвороб олійних пальм, 3 історії латиноамериканського бізнесу публікуються в основному журналами з низькими рейтингами, тому отримують незначне визнання і підтримку донорів, хоча подібні дослідження мають велике значення для соціально-економічного розвитку Латинської Америки. Тому не можна вважати «сміттєвими» публікації у виданнях з низькими чи відсутніми рейтингами. У країнах з низьким та середнім рівнем достатку має визнаватися роль таких видань в поширенні потенційно нових і корисних знань, беручи до уваги упередженість глобальної монополістичної наукометрії на користь англомовних досліджень з США та північно-західної Європи (Chavarro, Tang, Ràfols, 2017).

У формуванні державної наукової політики Міністерство освіти та науки України покладає великі сподівання на співпрацю 3 монополістичними наукометричними системами, зокрема, висуваючи вимоги наявності публікацій у виданнях, які індексуються Scopusчи Web of Science, для присвоєння вчених звань. Проте формально-правове закріплення перебільшеного значення окремих міжнародних наукометричних систем у вітчизняній науці створює серйозні ризики для академічної свободи та національної безпеки (Sheliazhenko, 2017a). Монополії у сфері поширення наукових знань стають предметом публічного обговорення та критики не тільки в Україні: дискусія і тривожні попередження на сторінках газети «Голос України» у 2018 році співпали з виходом у тому ж році міжнародного документального фільму "Paywall: The Business of Scholarship". Тим не менше, незважаючи на шквал критики, українська політика державного регулювання наукових досліджень продовжує підлаштовуватися під амбіції глобальних монополій: останнім свідченням цього є вимога наявності публікацій, які індексуються у Scopus чи Web of Science, що висувається до членів спеціалізованих вчених рад відповідно до п. 6 Порядку проведення експерименту з присудження ступеня доктора філософії, затвердженого Постановою Кабінету Міністрів України № 167 від 06.03.2019 p.

Індексовані українські видання з соціальних і гуманітарних наук та дисциплін можна перелічити на пальцях, деякі з них були швидко виключені з наукометричних баз за неетичні видавничі практики. Юридичних індексованих видань нема, лише мала частина юристів мають індексовані публікації. Тим часом серед науковців завдяки нав'язливій рекламі послуг 
сумнівних ділків поширилося хибне переконання, ніби за кілька тисяч доларів можна опублікувати що завгодно в престижних виданнях.

Брак самостійності у науковій творчості та поширеність уявлень прокорумпованість науки вже не можна вважати суто внутрішніми проблемами України, оскільки подібні явища помічені на міжнародному рівні та впливають на репутацію нашої держави.

Огляд стану освіти в Україні за 2017 рік, підготовлений Організацією економічного співробітництва та розвитку (OECP), показує, що освіта в Україні характеризується порушеннями на всіх рівнях. Окремі розділи цього огляду присвячені корупції у доступі до вищої освіти, академічній непорядності, обману та плагіату в вищій освіті та неналежній оцінці академічних досягнень (OECD, 2017).

Опубліковане в грудні 2015 року дослідження Британської Ради свідчить, що студенти в Україні не розуміють значення участі в автономній академічній спільноті. На думку дослідників, до студентів ставляться майже як до дітей при навчанні в університетах та навіть у відносинах між дослідником і науковим керівником в аспірантурі (Higher Education in Ukraine: Briefing Paper, 2015).

Реагування на критику, озвучену на міжнародному рівні, не забарилося. Новим Законом України «Про освіту» від 05.09.2017 р. № 2145-VIII (On Education, 2017) передбачений захист автономії суб'єктів освітньої діяльності та академічних свобод учасників освітнього процесу. Статтею 42 закону приписується обов'язок дотримуватися академічної доброчесності, тобто етичних принципів та визначених законом правил для забезпечення довіри до результатів навчання та наукових і творчих досягнень, а також встановлено форми відповідальності працівників закладів освіти та здобувачів освіти за порушення академічної доброчесності, зокрема, академічний плагіат, самоплагіат, фабрикацію, фальсифікацію, списування, обман, хабарництво, необ'єктивне оцінювання.

Водночас, формальних гарантій академічної свободи та санкцій за прояви академічної недоброчесності, встановлених законом, недостатньо для реального розвитку особистої автономії українських науковців.

Зміни законодавства лише створюють передумови для реформ, які мають плануватися і здійснюватися автономно на рівні університетів та інших академічних установ. Створення інфраструктури успішної та самостійної наукової діяльності, як можна передбачити, стане предметом конкуренції академічних спільнот України, їх боротьби за кращі мізки та гранти.

Законом не передбачено обов'язку університетів впроваджувати кодекси академічної етики. Але автономія дозволяє приймати рішення про 
власні етичні стандарти, і це напевне робитиметься відповідно до кращих світових практик та рекомендацій ОЕСР.

Набуватиме популярності вивчення стандартів англомовного академічного письма (academic writing) i розробка сучасних стандартів українського академічного письма, скоріше прагматичного - орієнтованого на результат - ніж формалістичного, що дозволяє прилаштувати до купи стандартних вимог пустослів'я замість нового та значущого наукового результату. Туманність, абстрактність, загальні фрази не вписуватимуться у прагматичний науковий стиль, культурні норми нового українського академічного письма.

В українську науку поступово проникатиме i західний алгоритм обов'язкового незалежного рецензування кількома рецензентами кожної запропонованої до публікації статті в науковий журнал, а також попереднього відбору доповідей на конференції на основі коротких (250-500 слів) рефератів та подальшого рецензування тез перед публікацією. Ці стандарти достатньо складні для дотримання, але завдяки їм у Європі та США підтримується висока планка наукової доброчесності; з цього варто брати приклад.

Шлях обструкції міжнародного науково-технічного співробітництва, мовно-культурного ізоляціонізму на противагу русифікації та англіїзації, до якого закликає Ірина Фаріон (Farion, 2018), навряд чи має перспективи в глобальному мультикультурному світі, де успіх націй пов'язаний з вмінням мирно знаходити спільну мову та взаємну вигоду, а не потугами нав'язувати свою мову силою та хизуватися шляхетною зневагою до фінансового капіталу. 3 іншого боку, нинішнє покоління українців справді зобов'язане подбати про збереження, примноження та передачу гідним нащадкам накопиченого попередніми поколіннями інтелектуального та культурного капіталу і самостійність своєї позиції в світовому науковому просторі. В цьому полягає наш національний інтерес, так само як і в підтриманні міжнаціонального науково-культурного діалогу: маємо, за настановою Тараса Шевченка, чужому навчатися і свого не цуратися.

Варто дослухатися до пропозицій Юлії Діденко та Анни Радченко щодо розвитку вітчизняної наукової видавничої справи та підтримки вчених, які реалізують проекти міжнародної співпраці, публікуються в англомовних виданнях (Didenko, Radchenko, 2017). Заслуговують на увагу ідеї розвитку вітчизняних електронних репозитаріїв наукових текстів (Chmyr, Kvasha, Yaroshenko, 2017) та наукометричних систем. Деякі успіхи в цьому напрямку вже досягнуті академічними бібліотеками, і продовження відповідних робіт потребує належної уваги, ресурсів та зусиль. Також, відповідно до пропозицій учасників конференції «Міжнародне науково-технічне співробітництво: принципи, механізми, ефективність» (Herasymchuk, 2017), необхідно 
заохочувати бізнес за допомогою спеціальних податкових режимів фінансувати українські наукові дослідження світового рівня і виходити з інноваційними продуктами на зарубіжні ринки. Інституційному розвитку і демократизації університетів може сприяти міні-грантова підтримка проектів наукових досліджень всередині університетів на конкурсній основі (Sheliazhenko, 2018).

\section{Висновки}

У підсумку, міжнародно-правовий стандарт особистої автономії в академічній культурі та науковому співробітництві передбачає прагнення індивідуальної й інституційної самостійності та відповідальності в пошуку та передачі знань, вимагає поваги до свободи наукових досліджень, академічного спілкування та вираження поглядів. Цей стандарт пов'язаний із людською гідністю, метою освітньої системи досягти здатності людини контролювати власне життя, дотримуватися законів власного здорового глузду, включаючи досвід досягнення спільного блага разом 3 іншими людьми, здатності застосовувати свободу волі для раціонального визначення і реалізації своєї індивідуальності та інтересів, заробляти на життя своїм розумом, бути успішним і щасливим громадянином у демократичному інформаційному суспільстві. Якісна організація наукової роботи на індивідуальному та інституційному рівні потребує взаємної довіри не менше, ніж взаємного контролю та вивірених норм наукової продуктивності. Загрозами особистій автономії науковців $є$ академічна недоброчесність, монополізм, патерналізм, формалізм та бюрократизм. Зазначені проблеми вирішуються у широкому та відвертому науковому спілкуванні, шляхом приватних та публічних ініціатив, спрямованих на очищення та розвиток науки, створення комфортних і дієвих норм академічної культури та безпечного наукового співробітництва. Окрім загальних проблем світової науки, пов'язаних із монополізмом у видавництві наукових журналів, оцінюванні якості та фінансуванні наукових досліджень, Україна має впоратися з власними проблемами ізоляціонізму, бідності та корупції. Новий Закон України «Про освіту» створює інструменти для боротьби 3 академічною недоброчесністю та дозволяє проявляти ініціативу для удосконалення науки та освіти. Українська академічна культура потребує оновлення, щоб підняти рівень наукових досліджень і створити основу конкурентоспроможної інноваційної економіки, зберегти i примножити матеріальні та духовні надбання української нації в глобальному світі, де стають жорсткішими кордони для злочинності та водночас стираються кордони для наукового прогресу, культурного різноманіття, обміну науковою інформацією, навчання та вигідного співробітництва. Необхідно розбудовувати українську інфраструктуру наукової інформації, вітчизняні видавництва, системи індексації та бібліотеки, посилювати правові гарантії особистої автономії, підтримувати проекти міжнародного науково-технічного 
співробітництва, впровадження наукових розробок у економіці та суспільному житті.

\section{References:}

1. Chavarro, D., Tang, P., Ràfols, I. (2017). Why researchers publish in nonmainstream journals: Training, knowledge bridging, and gap filling, Research Policy, no. 46 (9), pp. 1666-1680.

2. Chmyr, O. S., Kvasha T. K., Yaroshenko T. O. (2017). Natsionalnyi repozytarii akademichnykh tekstiv: vidkrytyi dostup do naukovoi informatsii [National Repository of Academic Texts: Open Access to Scientific Information]. Kyiv: UkrINTEI.

3. Didenko, Y., Radchenko A. (2017). Publikatsiina aktyvnist yak sposib naukovoi komunikatsii ta honytvy za reitynhamy [Publication Activity as a Way of Scientific Communication and Ratings Race]. Visnyk of the NAS of Ukraine [Bulletin of the National Academy of Sciences of Ukraine], no. 9, pp. 82-98.

4. Eve, M., Priego, E. (2017). Who is Actually Harmed by Predatory Publishers?' TripleC, no. (15), pp. 755-770.

5. Farion, I. (2018). Vidkrytyi lyst Ministrovi osvity L. Hrynevych pro denatsionalizatsiiu osvity ta nauky [Open Letter to the Minister of Education L. Hrynevych Concerning Denationalization of Education and Science]. Available at: http://blogs.pravda.com.ua/authors/farion/5a9478ac25e51/.

6. Herasymchuk, V.H. (2017). Mizhnarodne naukovo-tekhnichne spivrobitnytstvo: pryntsypy, mekhanizmy, efektyvnist. Zbirnyk prats XIII Vseukrainskoi naukovo-praktychnoi konferentsii (Kyiv, 16-17 bereznia 2017 roku) [International Cooperation in Science and Engineering: Principles, Mechanisms, Efficacy. Collection of Papers Presented at XIII Ukrainian Applied Science Conference (Kyiv, 16-17 March 2017)]. Kyiv: Politekhnika.

7. Higher Education in Ukraine: Briefing Paper. (2015). British Council, [online]. Available at: https://www.britishcouncil.org/sites/default/files/ukraine_he_briefing_paper.pdf.

8. Jaffe, K., Caicedo, M., Manzanares, M., Gi,l M., Rios, A., Florez, A. (2013). Productivity in Physical and Chemical Science Predicts the Future Economic Growth of Developing Countries Better than Other Popular Indices. PLoS ONE, no. 8 (6). Available at: https://doi.org/10.1371/journal.pone.0066239.

9. Lynn, R, Vanhanen, T (2002). IQ and the Wealth of Nations. London: Praeger.

10. Marcus, A., Oransky, I. (2016). Why Fake Data When You Can Fake a Scientist? Making up names and CVs is one of the latest tricks to game scientific metrics. Available at: http://nautil.us/issue/42/fakes/why-fake-data-when-you-can-fake-ascientist. 
11. On Education: Law of Ukraine no. 2145-VIII dated from 5 September 2017. Verkhovna Rada of Ukraine. Available at: https://zakon.rada.gov.ua/laws/show/2145-19.

12. Report of the Special Rapporteur in the field of cultural rights United Nations. (2016). United Nations, [online]. Available at: http://undocs.org/A/HRC/31/59.

13. Reviews of Integrity in Education: Ukraine 2017. (2017). OECD. Paris, OECD Publishing. Available at: http://dx.doi.org/10.1787/9789264270664-en.

14. Ruttan, V. (2003). Social Science Knowledge and Economic Development: An Institutional Design Perspective. Ann Arbor: University of Michigan Press.

15. Sheliazhenko, Yu. (2017a). Monopolistychna naukometriia z tochky zoru akademichnoi svobody ta bezpeky. Informatsiia i pravo [Information and Law], no. 2(21), pp. 144-153.

16. Sheliazhenko, Yu. (2018). Uchast studentiv i aspirantiv v upravlinni universytetom yak harantiia akademichnoi svobody [Participation of Students, including Postgraduate Students, in University Self-Government as Guarantee of Academic Freedom]. Aktualni pytannia suchasnoi nauky ta praktyky. Materialy naukovo-praktychnoi konferentsii (15 lystopada 2018, Kyiv) [Actual Problems of Contemporary Science and Practice: Proceedings of Applied Science Conference (15 November 2018)]. Kyiv: KROK University. pp. 718-721.

17. Sheliazhenko, Yu. (2019). Academic autonomy and perspectives of interdisciplinary research: mathematical analysis of law. Scientific Papers of the Witelon State University of Applied Sciences in Legnica, no. 3 (32), pp. 155-62. Available at: https://www.academia.edu/40536083/.

18. Sheliazhenko, Yu.(2017). Akademichna avtonomiia naukovoho zhurnalu [Academic Autonomy of Scientific Journal]. Naukovi trendy suchasnosti: materialy naukovo-praktychnoi konferentsii (Kyiv, 26 zhovtnia 2017 roku) [Contemporary Scientific Trends: Proceedings of Applied Science Conference]. Kyiv: KROK University. pp. 283-285. Available at: https://www.academia.edu/35297249/.

19. Sorokowski, P., Kulczycki, E., Sorokowska, A., Pisanski, K. (2017) Predatory journals recruit fake editor. Nature, no. 543, pp. 481-483.

20. United Nations. (2014). 'Report of the Special Rapporteur in the field of cultural rights, Farida Shaheed, to the U.N. Human Rights Council', no. A/HRC/28/57. Available at: http://undocs.org/A/HRC/28/57.

21. Witte, F. (2017) From Scientific Progress to Economic Growth. Singapore: World Scientific.

(c) Шеляженко Ю. В., 2020 